\title{
Šaujamieroču pielietošanas tiesības un amatpersonu profesionālā izglïtība
}

\author{
Kitija Bite \\ Rīgas Stradiña universitāte, Juridiskā fakultāte, Latvija \\ kitija.bite@rsu.lv
}

\section{Kopsavilkums}

Katrā demokrātiskā sabiedrībā tiek ievērotas cilvēka pamattiesības un brīvības, kuras valsts atzīst par vērtību un aizsargā. Lai vērtības tiktu aizsargātas, valsts ar normatīvajiem aktiem ir paredzējusi tiesības ierobežot cilvēka pamattiesības un brīvības. Viena no pamattiesībām ir cilvēka tiesības uz dzīvību, kuru nav paredzēts ierobežot. No otras puses, valsts speciālajos likumos ir noteikusi tiesības valsts dienestā esošām personām pielietot šaujamieroci tikai likumdevēja uzskaitītajos gadījumos. Šāda situācija ḷauj prezumēt secinājumu, ka šaujamieroču pielietošanas gadijjumā var tikt apdraudētas valsts atzìtās cilvēka tiesības uz dzīvību un arī veselību. Lai nodrošinātu šaujamieroču pareizu pielietošanu, valstij ir jārada tiesiskais regulējums, kurš nosaka pietiekamu profesionālās izglîtibas sistēmu, kura ḷautu amatpersonai gūt profesionālu kompetenci.

Šajā darbā pētītas trīs iestādes, kuru amatpersonām ir tiesības pielietot šaujamieroci, - Valsts policija, Valsts robežsardze un Ieslodzijuma vietu pārvalde. Tajā dots ieskats šaujamieroču pielietošanas tiesiskajā regulējumā un analizēti tie normatīvie akti, kuri nosaka profesionālo kompetenču veidošanu ar formālo izglītỉbu. Raksta sagatavošanas laikā nebija stājušies spēkā Valsts policijas jaunākā un vecākā virsnieka standarti, rakstā analizēta informācija līdz 2015. gada 1. decembrim.

Atslēgvārdi: cilvēktiesības, galēja nepieciešamība, izglītības programma, profesijas standarts, profesionālā izglītība, studiju kurss, šaujamieroču pielietošana.

Darba mērḳis - izvērtējot šaujamieroču izmantošanas un profesionālās izglītības tiesisko regulējumu, izdalìt problēmas, kas saistītas ar profesionālo kompetenču iegūšanu, un ieteikt to risinājumu. 
Kitija Bite. Šaujamieroču pielietošanas tiesības un amatpersonu profesionālā izglītība

Materiāls un metodes - normatīvo aktu, tiesu prakses un zinātniskās literatūras analīze un apraksts, indukcijas un dedukcijas, kā arī grafiskā metode. Darbā izmantotas tiesību normu interpretācijas metodes: gramatiskā, sistēmiskā, vēsturiskā un teleoloğiskā metode.

Rezultāti. Valsts konstitūcija aizsargā cilvēka pamattiesības un brīvības, norādot, ka Latvijā tiek atzìtas demokrātiskas sabiedrības vērtības - cilvēka dzīvība. Šo vērtību valsts aizsargā tiktāl, ka nepiel̦auj tās ierobežošanu, tādējādi pasludinot cilvēka dzīvību par absolūtu cilvēktiesību. Tomēr valsts arī paredz - lai aizsargātu sabiedrību un tās vērtības no prettiesiskiem apdraudējumiem, speciālajās tiesību normās ir dota iespēja valsts amatpersonām pielietot šaujamieroci. Tas rada iespējamību, ka cilvēka dzīvība tomēr nav absolūta cilvēka pamattiesība.

Izpētot triju valsts iestāžu - Valsts policijas, Valsts robežsardzes un Ieslodzijuma vietu pārvaldes - amatpersonu ar likumu noteiktās tiesības pielietot šaujamieroci, autore secina, ka valsts ir noteikusi gadījumus, kad šaujamieroci drīkst pielietot. Lai amatpersona varētu adekvāti izmantot likumā noteiktās tiesības, tai ir jābūt profesionāli labi sagatavotai, respektīvi, amatpersonai ir jāpiemīt tām kompetencēm, kas noteiktas profesijas standartā un kuras nepieciešamas dienesta pienākumu izpildei augstā līmenī. Jāsecina, ka Valsts policijas darbiniekiem nav izstrādāts neviens profesijas standarts, tāpēc nav iespējams izveidot profesionālās izglitības programmu, kura ḷautu nepieciešamās kompetences iegūt. Valsts robežsardze un Ieslodzijuma vietu pārvalde profesijas standartā ir iekḷāavusi zināšanas, prasmes un iemaṇas, pēc kuru apgūšanas būtu jāveidojas profesionālai kompetencei - prasmei izmantot šaujamieročus. Tomēr arī šo izglītības iestāžu programmās vērojamas nianses, kuras jānovērš, lai amatpersonas iegūtu atbilstošas profesionālās kompetences.

\section{Diskusija}

Latvijas sabiedrības politiskie pārstāvji 1918. gada 18. novembrī vienojās, ka turpmāk vēlas dzīvot demokrātiskā tiesiskā valstī $[4,176]$. No šìs pamattēzes 1922. gadā tika veidota Latvijas Republikas Satversme [11] un pien,emti turpmākie normatīvie akti, kuri nedrīkst būt pretrunā ne ar pamattēzi, ne Satversmi. Valsts kā visas tautas organizēta kopība un publiskās administrācijas subjekts var ìstenot savu varu un funkcijas tikai caur varas nodošanu. Tāpēc valsts dalı savas varas nodod (delegeē) publiski tiesiskām juridiskām personām. Delegeěšana notiek ar likumu palīdzību, balstoties uz stingri noteiktu kompetenci $[3,88]$.

Jautājumā par šaujamieroča pielietošanu valsts ar likumu palīdzību ir delegeejusi daḷu savas varas, respektīivi, sabiedriskās kārtības un iekšējās drošības funkciju, ìstenot dažām iestādēm uz likuma pamata (salīdzinājums 1. tabulā), nosakot šo iestāžu darbības mērḳi, no kura izriet funkcijas / uzdevumu delegējumi. Lïdz ar delegeējumu ir noteikta šo iestāžu kompetence - šaujamieroču pielietošana, lai iestāde varētu sasniegt delegèeto mērḳi. 
Kitija Bite. Šaujamieroču pielietošanas tiesības un amatpersonu profesionālā izglītība

1. tabula. Iestāžu darbības mērḳis

\begin{tabular}{|c|c|c|}
\hline $\begin{array}{l}\text { Valsts policija } \\
{[13,1 \text {. pants }]}\end{array}$ & $\begin{array}{c}\text { Valsts robežsardze } \\
{[17,2 \text {. pants }]} \\
\end{array}$ & $\begin{array}{c}\text { leslodzijuma vietu pārvalde } \\
{[8,2 \text {. pants }]}\end{array}$ \\
\hline $\begin{array}{l}\text { Apbruņota militarizēta valsts } \\
\text { vai pašvaldības institūcija, kuras } \\
\text { pienākums ir aizsargāt personu } \\
\text { dzīvību, veselību, tiesības un } \\
\text { brīvības, īpašumu, sabiedrības } \\
\text { un valsts intereses no noziedzī- } \\
\text { giem un citiem prettiesiskiem } \\
\text { apdraudējumiem. }\end{array}$ & $\begin{array}{l}\text { lekšlietu ministra pārraudzībā } \\
\text { esoša tiešās pārvaldes iestāde. } \\
\text { Robežsardze ir bruṇota, un tās } \\
\text { funkcijas ir valsts robežas neaiz- } \\
\text { skaramības nodrošināšana un } \\
\text { nelegālās migrācijas novēršana. }\end{array}$ & $\begin{array}{l}\text { Tieslietu ministrijas padotībā } \\
\text { esoša valsts pārvaldes iestāde, } \\
\text { kas īsteno valsts politiku apcie- } \\
\text { tinājuma kā drošības līdzekḷa un } \\
\text { brīvības atṇemšanas kā krimināl- } \\
\text { soda izpildes jomā. }\end{array}$ \\
\hline
\end{tabular}

Satversmē kā augstākā ranga juridiskajā dokumentā ir deklarēts - valsts atzīst ikviena tiesības uz dzīvību, ko aizsargā likums [11, 93. pants], un valsts aizsargā cilvēka veselību [11, 111. pants]. No Satversmes 116. panta izriet, ka šìs normas nevar ierobežot ar likuma palīdzỉbu. Kā atzinis E. Levits, šis Satversmes pants uzskatāms par Satversmes 8. nodaḷas viskomplicētāko un arī visvājāko konstrukciju, jo Satversmes tekstā expresis verbis formā nav paredzēta iespēja ierobežot vairākas Satversmē noteiktās pamattiesības (piemēram, Satversmes 90., 110.-115. pants) [12, 760, 763]. No tā var secināt, ka cilvēka dzīvība un veselība ir uzskatāma par absolūtu tiesību.

Eiropas cilvēktiesību un pamatvērtību aizsardzības konvencija nosaka, ka dzīivibas atņemšana nav uzskatāma par konvencijas pārkāpumu, ja tas notiek spēka pielietošanas rezultātā, nepārsniedzot galējas nepieciešamības robežas. Un konvencijā izdalīti trīs gadỉjumi, kad galēja nepieciešamība tiks uzskatīta par pārkāpumu: 1) lai aizstāvētu jebkuru personu pret nelikumīgu vardarbību; 2) lai veiktu tiesisku aizturēšanu vai aizkavētu tiesiski aizturētas vai apcietinātas personas izbēgšanu; 3) lai saskaṇā ar likumu savaldītu dumpi vai apvērsumu [5, 2. panta otrā daḷa].

Redzams, ka konvencijas, kuru vispārīgās vadlīnijas ir uzskaitītas, aptver plašu jautājumu loku, paredzot spēka un arī šaujamieroča pielietošanu īpašos gadījumos. Mūsdienu krimināltiesību doktrīna l̦auj atbalstìt viedokli, ka ikvienai personai, kas apzinās apdraudējuma esamību, ir tiesības aktīvi aizsargāt svarīgu interesi, pat nodarot kaitējumu citām mazāk svarīgām vērtībām [10, 140].

Deklarācija par policiju nosaka, ka, veicot savus pienākumus, policijas ierēdnis pielieto visus iespējamos līdzekḷus tāda mērḳa sasniegšanai, kas ir tiesiski prasīts vai atḷauts, tomēr viṇš nedrīkst pielietot vairāk spēka, nekā tas saprātīgi nepieciešams $[6,12$. punkts $]$.

Konvencijā un deklarācijā ietverto regulējumu Latvijā likumdevējs ir iestrādājis speciālajās tiesību normās $[8,13,17]$, tajās paredzot, ka tiesības uz dzīvību un veselību nav absolūtas. Tas tāpēc, ka pētījumā iekḷauto iestāžu kompetencē ir paredzētas tiesības pielietot šaujamieroci. Tātad valsts prezumē, ka tiesības uz dzīvību un veselību var tikt aizskartas, ja pati persona ir bijusi iniciatore sabiedriskās kārtības un drošības apdraudējumam, respektīvi, ar savu rīcību ir radījusi situāciju, kuras novēršanai ir jāizmanto 
likumdevēja atḷautā šaujamieroča pielietošana. Krimināltiesību teorijā atzīts, ka galējās nepieciešamības pamatā ir vēlme aizsargāt svarīgas intereses. Tās pamatā ir arī interešu kolīzija. Abas intereses - aizsargājamo un to, kurai nodarīts kaitējums, - tiesiski nodrošina likums, bet bezizejas situācijā likums aț̣auj nodarìt kaitējumu vienai interesei $[1,11.1$. apakšpunkts].

Valsts ar likumu ir uzskaitījusi visus gadijjumus, kuriem iestājoties šaujamieroča pielietošana tiek uzskatīta par attaisnojamu (galēja nepieciešamỉba un pēkšn,s uzbrukums). Pētījuma autore pārskatāmības labad šaujamieroča pielietošanas gadījumus apkopojusi 2. tabulā, lai attēlotu katras iestādes šaujamieroča pielietošanas kompetenci, kuras apjoms izriet no valsts delegēetās funkcijas.

2. tabula. Tiesības pielietot šaujamieroci

\begin{tabular}{|c|c|c|}
\hline $\begin{array}{l}\text { Valsts policija } \\
{[13,14 . \text { pants }]}\end{array}$ & $\begin{array}{c}\text { Valsts robežsardze } \\
{[17,18 . \text { pants }]}\end{array}$ & $\begin{array}{c}\text { leslodzijuma vietu pārvalde } \\
{[8,24 \text {. pants }]}\end{array}$ \\
\hline 1 & 2 & 3 \\
\hline \multicolumn{3}{|c|}{ Tiesības pielietot šaujamieroci galējas nepieciešamības gadījumā } \\
\hline $\begin{array}{l}\text { Lai aizsargātu citas personas } \\
\text { un sevi no uzbrukuma, kas reāli } \\
\text { apdraud dzīvību vai var nodarīt } \\
\text { kaitējumu veselībai, novērstu } \\
\text { mēǵinājumu vardarbīgi iegūt } \\
\text { šaujamieroci. }\end{array}$ & $\begin{array}{l}\text { Lai aizturētu valsts robežas } \\
\text { pārkāpēju, ja nav citas iespējas } \\
\text { viṇu aizturēt. }\end{array}$ & $\begin{array}{l}\text { Lai novērstu apcietinātā vai } \\
\text { notiesātā bēgšanu, aizturētu } \\
\text { izbēgušu apcietināto vai } \\
\text { notiesāto. } \\
\text { Lai pārtrauktu personu neli- } \\
\text { kumīgu vardarbīgu ieklūššnu } \\
\text { ieslodzījuma vietā. }\end{array}$ \\
\hline Lai atbrīvotu k̦īlniekus. & - & - \\
\hline $\begin{array}{l}\text { Lai atvairītu grupveida vai } \\
\text { bruņotu uzbrukumu poli- } \\
\text { cijas darbiniekiem vai citām } \\
\text { personām, kuras pilda dienesta } \\
\text { pienākumus sabiedrības } \\
\text { drošības garantēšanā un cīñā } \\
\text { pret noziedzību. }\end{array}$ & $\begin{array}{l}\text { Lai atvairītu bruṇotu iebrukumu } \\
\text { Latvijas teritorijā vai izbeigtu } \\
\text { uzbrucēju bruṇotu pretošanos. }\end{array}$ & $\begin{array}{l}\text { Lai aizstāvētos pret personām, } \\
\text { kuras reāli apdraud viṇa vai citu } \\
\text { personu dzīvību vai veselību. }\end{array}$ \\
\hline $\begin{array}{l}\text { Lai atvairītu grupveida vai } \\
\text { bruṇotu uzbrukumu apsar- } \\
\text { gājamiem objektiem, telpām, } \\
\text { celtnēm, iestādēm, privāto } \\
\text { tiesību juridiskajām personām } \\
\text { un personu apvienībām. }\end{array}$ & $\begin{array}{l}\text { Lai atvairītu uzbrukumu un } \\
\text { izbeigtu pretošanos, arī neap- } \\
\text { bruṇotu personu uzbrukumu } \\
\text { un pretošanos, ja tiek radīti } \\
\text { reāli draudi robežsarga vai citu } \\
\text { personu dzīvībai un citādā } \\
\text { veidā tos nav iespējams novērst } \\
\text { vai ja ir nepieciešams novērst } \\
\text { mēǵinājumu vardarbīgi iegūt } \\
\text { šaujamieroci. }\end{array}$ & $\begin{array}{l}\text { Ja ieslodzījuma vietā notiek ar } \\
\text { grautiṇiem, dedzināšanu vai } \\
\text { kīlnieku sagrābšanu saistītas } \\
\text { masu nekārtības, masveida } \\
\text { pretošanās amatpersonām un } \\
\text { ja ar citiem līdzekḷiem pārtraukt } \\
\text { šīs darbības nav iespējams, } \\
\text { šaujamieročus drīkst pielietot } \\
\text { pēc tieslietu ministra, Tieslietu } \\
\text { ministrijas valsts sekretāra, } \\
\text { pārvaldes priekšnieka vai viṇa } \\
\text { vietnieka mutvārdu rīkojuma. }\end{array}$ \\
\hline
\end{tabular}


Kitija Bite. Šaujamieroču pielietošanas tiesības un amatpersonu profesionālā izglītība

\section{2. tabulas turpinājums}

\begin{tabular}{|c|c|c|}
\hline 1 & 2 & 3 \\
\hline $\begin{array}{l}\text { Lai aizturētu personu, kura } \\
\text { izrāda bruñotu pretošanos vai } \\
\text { kura pārsteigta smaga vai sevišḳi } \\
\text { smaga nozieguma izdarǐšanas } \\
\text { brīdī, vai izbēgusi no apcietinā- } \\
\text { juma, kā arī lai aizturētu apbru- } \\
\text { notu personu, kura atsakās } \\
\text { izpildīt likumīgu prasību nodot } \\
\text { ieroci vai sprāgstvielas. }\end{array}$ & - & $\begin{array}{l}\text { Lai aizturētu personu smaga } \\
\text { vai sevišksi smaga nozieguma } \\
\text { izdarīšanas brīdī vai tūlīt pēc } \\
\text { tā izdarǐšanas. } \\
\text { Lai aizturētu personu, kura } \\
\text { izrāda bruņotu pretošanos vai } \\
\text { atsakās izpildīt amatpersonas } \\
\text { likumīgo prasību nodot ieroci } \\
\text { vai sprāgstvielas. }\end{array}$ \\
\hline $\begin{array}{l}\text { Lai apturētu transportlīdzekli, } \\
\text { nodarot tam bojājumus, ja tā } \\
\text { vadītājs ar savu rīcību rada } \\
\text { reālus draudus personu dzīvībai } \\
\text { un veselībai un nepaklaujas poli- } \\
\text { cijas darbinieka prasībai apstā- } \\
\text { dināt transportlīdzekli un ja nav } \\
\text { citas iespējas viṇu aizturēt. }\end{array}$ & $\begin{array}{l}\text { Lai apturētu transportlīdzekli, } \\
\text { nodarot tam bojājumus, ja tā } \\
\text { vadītājs ar savu rīcību rada reālus } \\
\text { draudus robežsarga vai citu } \\
\text { personu dzīvībai un veselībai un } \\
\text { nepakl̦aujas robežsarga prasībai } \\
\text { apstādināt transportlīdzekli, un } \\
\text { nav citas iespējas viṇu aizturēt. }\end{array}$ & - \\
\hline $\begin{array}{l}\text { Lai padarītu nekaitīgu dzīvnieku, } \\
\text { kurš apdraud cilvēka dzīvību vai } \\
\text { veselību. }\end{array}$ & - & - \\
\hline $\begin{array}{l}\text { Lai dotu trauksmes signālu vai } \\
\text { izsauktu palīdzību. }\end{array}$ & $\begin{array}{l}\text { Lai dotu trauksmes signālu vai } \\
\text { izsauktu palīdzību. }\end{array}$ & - \\
\hline- & - & $\begin{array}{l}\text { Lai novērstu mēǵinājumu } \\
\text { vardarbīgi iegūt šaujamieroci. }\end{array}$ \\
\hline
\end{tabular}

\begin{tabular}{|c|c|c|}
\hline \multicolumn{3}{|c|}{ Tiesības pielietot šaujamieroci bez brīdinājuma } \\
\hline $\begin{array}{l}\text { Ja uzbrukums ir pēkšņs vai } \\
\text { uzbrukumā tiek izmantoti ieroči, } \\
\text { kaujas tehnika, jebkura veida } \\
\text { mehāniskie transportlīdzekḷi. }\end{array}$ & $\begin{array}{l}\text { Ja uzbrukums ir pēkšñs vai } \\
\text { uzbrukumā tiek izmantoti ieroči } \\
\text { vai jebkura veida mehāniskie } \\
\text { transportlīdzekḷi. }\end{array}$ & $\begin{array}{l}\text { Ja notiek pēkšñs bruņots uzbru- } \\
\text { kums ieslodzījuma vietai. } \\
\text { Ja notiek pēkšn, brun,ots } \\
\text { uzbrukums amatpersonai } \\
\text { vai citai personai, kā arī tad, } \\
\text { ja uzbrukumā tiek izmantots } \\
\text { transportlīdzeklis. }\end{array}$ \\
\hline $\begin{array}{l}\text { Ja tas nepieciešams kīlnieku } \\
\text { atbrīvošanai. }\end{array}$ & - & $\begin{array}{l}\text { Ja tas nepieciešams k̦īlnieka } \\
\text { atbrīvošanai. }\end{array}$ \\
\hline $\begin{array}{l}\text { Ja notiek bēgšana no apcieti- } \\
\text { nājuma, pielietojot ieroci vai } \\
\text { izmantojot transportlīdzekli, vai } \\
\text { notiek apcietināto bēgšana no } \\
\text { transportlīdzekḷa tā braukšanas } \\
\text { laikā. }\end{array}$ & - & $\begin{array}{l}\text { Ja notiek bēgšana no ieslodzī- } \\
\text { juma vietas, pielietojot ieroci vai } \\
\text { izmantojot transportlīdzekli, kā } \\
\text { arī tad, ja bēgšana notiek naktī } \\
\text { vai sliktas redzamības apstākḷıs, } \\
\text { vai no transportlīdzekḷa tā } \\
\text { braukšanas laikā, vai bēgšana } \\
\text { notiek grupā. }\end{array}$ \\
\hline - & - & $\begin{array}{l}\text { Ja tiek aizturēts apcietinātais vai } \\
\text { notiesātais, kurš izrāda brun,otu } \\
\text { pretošanos. }\end{array}$ \\
\hline
\end{tabular}


Kitija Bite. Šaujamieroču pielietošanas tiesības un amatpersonu profesionālā izglītība

No likuma regulējuma redzams, ka uzskaitījums ir stingri noteikts un ne iestāde, ne amatpersona to nevar paplašināt. Tāpēc normas piemērotājam šis uzskaitījums uzliek pienākumu interpretēt un piemērot tiesību normas - piepildīt ar saturu likumā ietvertos jēdzienus. Tādējādi būtisks kḷust jautājums par personu, kuras pielieto šaujamieroci, profesionālo sagatavotību un zināšanu un praktisko iemaṇu pastāvīgu papildināšanu. Tāpēc raksta turpmākajā dạ̣ā autore analizēs katras iestādes izveidoto izglìtības sistēmu un rīcību, profesionāli sagatavojot amatpersonas rīcībai ar šaujamieroci.

Konkretizējot tiesību normās šaujamieroča pielietošanu, likumdevējs ir radījis pozitīvās tiesības, kuras sniedz objektīvas tiesības pielietot šaujamieroci (bet ir iespējams, ka amatpersonai šìs objektīvās tiesības nekad nevajadzēs ìstenot) un uzliek subjektīvos pienākumus, kad šaujamieroci pielietot (atl̦aut pielietot un noteikt, kad pielietot). Tādējādi subjektīvais pienākums piekrīt arī valstij - ievērot tās objektīiās tiesības, kuras pati valsts - likumdevējs - ir ietvēris pozitīvās likuma normās. Viens no valsts pienākumiem ir nodrošināt izglīīibas sistēmu, kuras rezultātā topošais profesionālis iegūst attiecīgas kompetences (zināšanas, prasmes, iemaṇas un attieksmi), lai varētu ìstenot valsts noteikto iestādes mērḳi, tostarp pielietot šaujamieroci.

Valsts ir noteikusi tās profesijas, kuras Latvijā atzìtas par leǵitīmām. Uzskaitījums ir dots Profesiju klasifikatorā [14]. Autore pētīja tikai 2.-4. profesionālās kvalifikācijas līmeni (turpmāk - PKL), jo izglìtības iestādes realizē šis programmas. Profesiju klasifikatorā mazās grupas "335 Valsts varas îstenošanas speciālisti” (policijas darbinieks, robežsargs) kompetences noteiktas šādi: zina (šeit un turpmāk tekstā autores teksta izcēlumi): uzdotā darba izpildes teorētiskos un praktiskos pamatus; prot: lietot praksē teorētiskās zināšanas, tās pastāvīgi papildināt; pašizglìtoties; lietot ieroci un aizsargāt sevi un citus no iespējamiem uzbrukumiem; atbild: par savas profesionālās darbības rezultātiem; par uzdotā darba norisi un rezultātiem; par paša pieṇemtajiem lēmumiem; par uzticētajiem darba līdzekḷiem un priekšmetiem; par citu savā darbỉbā skarto personu drošỉbu; izglītība: augstākā izglìtība, dažos gadījumos - vidējā profesionālā izglìīiba [14, 335 mazā grupa].

“3355 Iekšlietu inspektori un izmeklētāji” (netika iekḷauti inspektori nodokḷu jomā un pašvaldỉbas policijas darbinieki):

708.1. Policijas INSPEKTORS - profesijas kods “3355 01”;

708.5. Vecākais INSPEKTORS (iekšlietu jomā) - profesijas kods “3355 05”;

708.6. Vecākais INSPEKTORS - posteṇa KOMANDIERIS (iekšlietu jomā) - profesijas kods "3355 06";

708.7. Valsts robežsardzes INSPEKTORS - profesijas kods “3355 07”;

708.9. Valsts robežsardzes vecākais VIRSNIEKS - profesijas kods "3355 09”;

708.10. Sevišķi svarīgu lietu INSPEKTORS (iekšlietu jomā) - profesijas kods “3355 10”;

708.11. Vecākais iecirkṇa INSPEKTORS (iekšlietu jomā) - profesijas kods “3355 11”;

708.12. Seviški svarīgu uzdevumu INSPEKTORS (iekšlietu jomā) - profesijas kods “3355 12”;

708.13. INSPEKTORS (iekšlietu jomā) - profesijas kods “3355 13”;

708.15. INSPEKTORS - KRIMINĀLISTS (iekšlietu jomā) - profesijas kods “3355 15”; 
Kitija Bite. Šaujamieroču pielietošanas tiesības un amatpersonu profesionālā izglītība

708.16. INSPEKTORS - SAPIERIS (iekšlietu jomā) - profesijas kods “3355 16”; 708.17. INSPEKTORS - SNAIPERIS (iekšlietu jomā) - profesijas kods “3355 17”; 708.18. INSPEKTORS - KINOLOGS (iekšlietu jomā) - profesijas kods “3355 18”; 708.19. DežūrINSPEKTORS (iekšlietu jomā) - profesijas kods “3355 19”; 708.20. DežūrINSPEKTORS - vada KOMANDIERIS (iekšlietu jomā) - profesijas kods “3355 20";

708.21. Iecirkṇa INSPEKTORS (iekšlietu jomā) - profesijas kods “3355 21”;

708.22. Ceḷu policijas INSPEKTORS (iekšlietu jomā) - profesijas kods “3355 22”;

708.23. Administratīvās prakses INSPEKTORS (iekšlietu jomā) - profesijas kods “3355 23”;

708.24. INSPEKTORS - DEŽURANTS (iekšlietu jomā) - profesijas kods "3355 24";

708.25. INSPEKTORS (KINOLOGS - SAPIERIS) (iekšlietu jomā) - profesijas kods “335525”;

708.28. Valsts robežsardzesjaunākais VIRSNIEKS(iekšlietujomā) - profesijas kods "335528”;

708.29. Jaunākais INSPEKTORS (iekšlietu jomā) - profesijas kods “3355 29”;

708.30. Jaunākais INSPEKTORS - SAPIERIS (iekšlietu jomā) - profesijas kods “3355 30";

708.31. Jaunākais INSPEKTORS - KINOLOGS (iekšlietu jomā) - profesijas kods “3355 31”;

708.35. KĀRTİBNIEKS (iekšlietu jomā) - profesijas kods “3355 35”;

708.36. Jaunākais KĀRTĪBNIEKS (iekšlietu jomā) - profesijas kods “3355 36”;

708.38. Koledžas KADETS (iekšlietu jomā) - profesijas kods “3355 38”.

Profesiju klasifikatorā tiek izdalītas trīs dažādu veidu profesijas: policijas inspektors - viena profesija; 23 profesijas, kurām tiek norādìta darbība iekšlietu jomā, un trīs profesijas robežsardzes jomā. Vēl Profesiju klasifikatorā ir ietverta profesija atsevišķā grupā "5412" - policisti, kuri sargā sabiedrisko kārtỉbu, nodrošina likumu un instrukciju izpildi. Tomēr šì profesija ir jānodala no atseviškāa grupas "335", jo tā neīsteno valsts varu. Tātad var pienemt, ka Valsts policijas profesijas var tikt īstenotas arī iekšlietu jomā, tādējādi ir 24 profesijas policijas darbiniekiem un trīs robežsargiem.

Šìs uzskaitîtās profesijas ir signāls augstākās izglìtības iestādēm, ka valsts atzīst šādu profesiju pārstāvju darbību Latvijas teritorijā un ir nepieciešamas izglīīibas programmas, kuras sagatavo topošos profesionāl̦us. Lai to varētu ìstenot, Profesiju klasifikatorā ir ietvertas jau tekstā iepriekš norādītās kompetences. Šo kompetenču apgūšanai / iegūšanai ir jāizstrādā profesijas standarts, kas ir Profesiju klasifikatora daḷa un nosaka profesijai atbilstošos profesionālās darbības pamatuzdevumus un pienākumus, profesionālās kvalifikācijas pamatprasības, to izpildei nepieciešamās vispārējās un profesionālās zināšanas, prasmes, attieksmes un kompetences. Citiem vārdiem sakot, tie ir vienoti kritēriji, kuri jāizpilda, lai persona varētu tikt uzskatīta par profesijai atbilstīgu. Profesijas standartu veido saskan̄ā ar Ministru kabineta noteikumiem [16] trīspusējā procesā - izglīîibas iestādes, nozares pārstāvji un darba devēji. Tikai pēc profesijas standarta izstrādes izglìīibas iestādei ir tiesības izstrādāt programmu, lai sagatavotu jauno speciālistu atbilstīgu kompetenču iegūšanai.

Atgriežoties pie mazās grupas “335”, jāsecina, ka Valsts robežsardzē ir izstrādāti profesijas standarti visām trijām profesijām. Bet nevienai policijas profesijai (tostarp iekšlietu jomā) nav izstrādāts profesijas standarts. Izglìtības un zinātnes ministrija ir 
nozīmējusi ekspertus Profesionālās izglītības un nodarbinātības trīspusējās sadarbības apakšpadomei divu standartu izstrādei - Valsts policijas vecākais virsnieks un Valsts policijas jaunākais virsnieks [9]. Tajā pašā laikā Nacionālajā izglīiības iespēju datubāzē parādās spēkā neesoši policijas profesijas standarti sadaḷā pie aktuālajiem uzṇemšanas noteikumiem Valsts policijas izglīīibas iestādēs gan 2. PKL [7], gan 4. PKL [18]. Vai to var uzskatìt par apzinātu reflektantu maldināšanu, ka izglïīibas iestādes īsteno programmas, kas nav izstrādātas atbilstīgi noteiktai kārtībai? Par to lai atbild atbildīgās amatpersonas, bet šajā pētỉjumā autore izmantoja minētos spēkā neesošos profesiju standartus, lai būtu iespējams izpētìt attiecīgajās izglìtības programmās ietvertās kompetences.

Valsts policijas spēkā neesošajos profesijas standartos bija noteiktas šādas prasības: 2. PKL - ierindas sastāva policists. Ne pie pienākumiem, ne uzdevumiem nav noteiktas specifiskas darbības ar šaujamieroci, tas ir jāatvasina no pienākumiem, piemēram, apturēt transportlīdzekli, nodrošināt sabiedrisko kārtību. Tomēr kā riska faktors darbā ir noteikts: paaugstinātas bīstamības risks - darbs ar ieročiem un speciāliem līdzekḷiem. Kopīgās prasmes profesijai - pielietot speciālos līdzekḷus un šaujamieročus. Pie zināšanām norādìts: šaujamieroču un speciālo līdzekḷu pielietošana, uzbūve un darbības principi - lietošanas līmenī.

Vidējā komandējošā (jaunākais virsnieks) sastāva policistam (4. PKL) - tieši tas pats. Kopīgās prasmes - pielietot speciālos līdzekḷus un šaujamieročus. Zināšanas lietošanas līmenī - šaujamieroču un speciālo līdzekḷ pielietošana, uzbūve un darbības principi. Jāsecina, ka šajos profesijas standartos neparādās atšķirības starp 2. PKL un 4. PKL, kas nav piel̦aujams, jo pēc būtības prasībām ir jāatškiras katrā profesionālās kvalifikācijas līmenī. To paredz Profesionālās izglīiības likums [15], nosakot, ka profesionālā kvalifikācija ir teorētiskā un praktiskā sagatavotỉba, kas dod iespēju veikt noteiktai sarežgitiības un atbildības pakāpei atbilstošu darbu $[15,1$. pants, otrā dalı,a, 9. punkts]. Tieši tāpēc profesionālā kvalifikācija ir iedalìta piecos līmeṇos, kuros atšķiras prasības konkrētas profesijas kvalifikācijas pakāpei [15, 5. pants]. Autore izsaka cerību, ka jaunajos profesijas standartos šāda rupja nepilnība netiks piel̦auta.

Valsts robežsardzes profesijas standarti diferencē izglìitibas / profesijas līmenuus, bet ir vērojamas arī nepilnības. Pārskatāmības labad autore informāciju izkārtojusi 3. tabulā.

Pašreizējie profesijas standarti paredz, ka kompetencēm jāpiemît tikai inspektoram; tādējādi izslēdzot, ka šīs kompetences būs nepieciešamas turpmāk karjeras laikā, respektīvi, ka ne jaunākajam, ne vecākajam virsniekam nebūs nepieciešamība izmantot subjektīvo pienākumu pozitīvo tiesību ietvaros. Prasmēm jābūt inspektoram un vecākajam virsniekam, pēc būtîbas diferencējot, ka inspektors pielieto vairākus šaujamieročus, bet vecākais virsnieks tikai dienesta šaujamieroci. Šāds formulējums paredz, ka jaunākajam virsniekam nebūs nepieciešamas konkrētās prasmēm. Vēl lielākas neprecizitātes vērojamas zināšanu apguvē: inspektors iegūst zināšanas priekšstata un 
Kitija Bite. Šaujamieroču pielietošanas tiesības un amatpersonu profesionālā izglītība

lietošanas līmenī; prasmes pielietot šaujamieročus un kompetenci nepieciešamības gadījumā lietot šaujamieročus. Jaunākajam virsniekam priekšstata līmenī ir zināšanas par šaujamieroču uzbūvi un darbības principiem un bruṇojuma apriti Valsts robežsardzē, bet lietošanas līmenī - šaujamieroču lietošana. Vecākajam virsniekam zināšanas noteiktas lietošanas līmenī par šaujamieroču uzbūvi un darbības principiem. Jāsecina, ka nav ievērota kompetenču un zināšanu pēctecība.

3. tabula. Profesionālās darbības pamatuzdevumu veikšanai nepieciešamās kompetences, prasmes un zināšanas saistībā ar šaujamieročiem

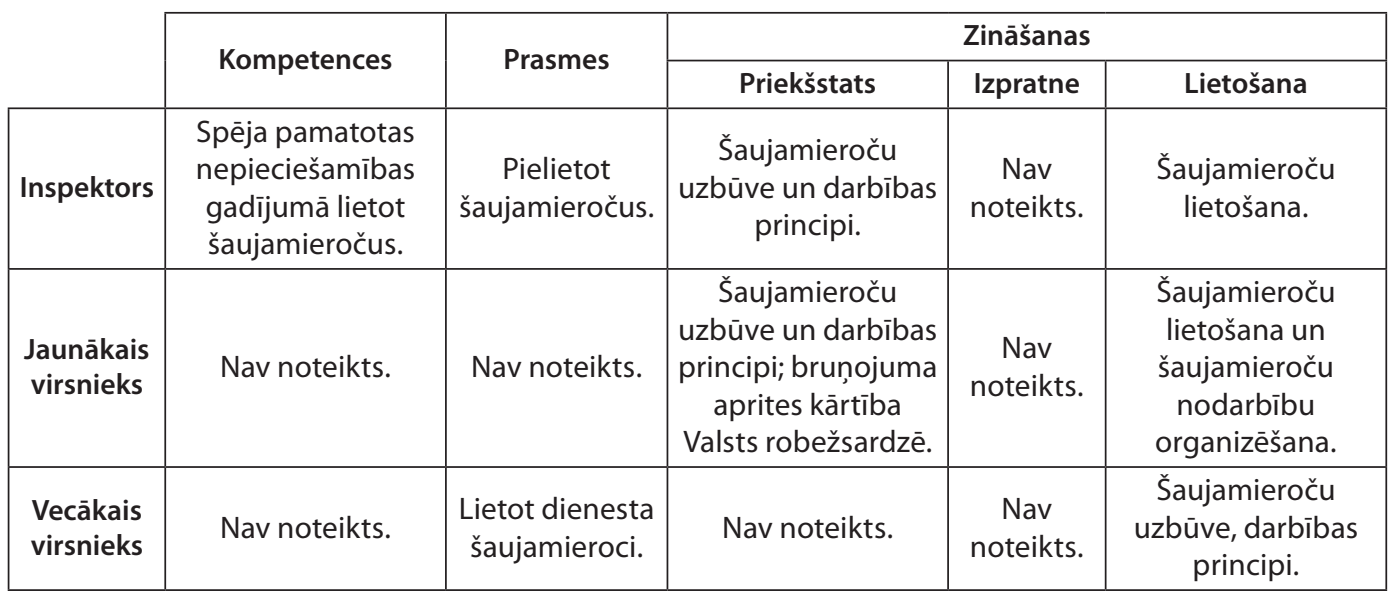

Vēl viena profesija, kurai noteikta šaujamieroču izmantošana, ir Ieslodzijuma vietu pārvalde. Profesiju klasifikatorā šīs profesijas noteiktas atsevišķā grupā 5413 “ieslodzijuma vietu apsardzes un uzraudzỉbas darbinieki”" [14, 5413 atsevišksa grupa]:

1045.1. Vecākais INSPEKTORS (apcietinājuma un brīvības atṇemšanas jomā) - profesijas kods "5413 01";

1045.2. Ieslodzijuma vietas vecākais INSPEKTORS - profesijas kods "5413 02";

1045.3. INSPEKTORS (apcietinājuma un brīvības atṇemšanas jomā) - profesijas kods "5413 03";

1045.4. Ieslodzījuma vietas INSPEKTORS - profesijas kods “5413 04”;

1045.5. Mācību centra INSPEKTORS (apcietinājuma un brīvības atnemšanas jomā) profesijas kods " 541305 ";

1045.6. Ieslodzījuma vietu pārvaldes centrālā aparāta jaunākais INSPEKTORS profesijas kods "5413 06";

1045.7. Ieslodzījuma vietas vecākais UZRAUGS - profesijas kods “5413 07”;

1045.8. Ieslodzijuma vietas UZRAUGS - profesijas kods “5413 08”;

1045.9. Ieslodzijuma vietas vecākais APSARGS - profesijas kods "5413 09";

1045.10. Ieslodzijuma vietas APSARGS - profesijas kods "5413 10";

1045.11. Ieslodzījuma vietas jaunākais INSPEKTORS - profesijas kods "541311". 
Kitija Bite. Šaujamieroču pielietošanas tiesības un amatpersonu profesionālā izglītība

Tātad kopā 11 profesijas, no kurām tikai vienai izstrādāts profesijas standarts. Acīmredzot iestāde izlēmusi, kurš profesijas standarts tai ir visnozīmīgākais, un izstrādājusi to, lai varētu īstenot izglìīibas programmu.

Ieslodzijuma vietu pārvaldes amatpersonām kā profesionālā kompetence noteikta spēja atbilstīgi situācijai izvēlēties un profesionāli lietot šaujamieročus; kā prasme noteikts normatīvajos aktos paredzētajos gadijjumos pielietot šaujamieročus. Savukārt nepieciešamās zināšanas noteiktas priekšstata līmenī - šaujamieroču uzbūve un darbības principi, bet lietošanas līmenī - šaujamieroču pielietošana. Vērojama pēctecība zināšanu jomā, kā arī noteiktas visas profesijas standartā iekḷautās jomas kompetence, prasmes un zināšanas.

Apkopojot analizēto informāciju par profesijas standartiem, autore secina, ka Valsts policijai nav spēkā esošu profesijas standartu, tāpēc izglìtības iestādēm nav dots leg̣itīms uzdevums - izstrādāt profesijas standartam atbilstīgas izglīiības programmas un sagatavot attiecīgus profesionāḷus, kā arī izsniegt diplomu par profesionālo kvalifikāciju. Valsts robežsardzei un Ieslodzijuma vietu pārvaldei profesijas standarti profesijas pamatuzdevumu veikšanai paredz profesionālās kompetences, prasmes un zināšanas. Tomēr vērojamas dažas neprecizitātes Valsts robežsardzes profesijas standartos.

Profesijas standartos iekḷautajām zināšanām par šaujamieroču izmantošanu ir noteiktas zināšanas gan priekšstata, gan lietošanas līmenī. Tātad šai pozịcijai obligāti jāatspoguḷojas izglīiības programmā. Autore pētīja arī vienu arodizglīiības programmu 2. PKL (policijas darbs), divas programmas 3. PKL (Valsts robežsardzes inspektors un Ieslodzījuma vietas pārvaldes jaunākais inspektors) un divas programmas 4. PKL (VRS jaunākais virsnieks un policijas darbs).

Izglītības programmas kritēriji apkopoti 4. tabulā (pielikumā).

Tajā redzams, ka Valsts policijas izglitības programmu mērḳis 2. PKL no 4. PKL vispār neatšķiras, kaut gan Profesionālās izglīīibas likums izdala piecus profesionālās kvalifikācijas līmen,us [15, 5. pants], lai diferencētu profesionalitātes pakāpes un tādējādi arī izglītības programmu saturu. Turklāt šo mērḳi paredzēts sasniegt ar krasi atšḳirīgu programmas apjomu - $39 \mathrm{KP}$ un $112 \mathrm{KP}$. Tajā pašā laikā atzinīgi vērtējams koledžas studiju kursa nosaukums "Šaušanas nepieciešamības izvērtēšanas stratēǵija”, kas paredz amatpersonas prasmi pieñemt lēmumu, izmantot šaujamieroci vai pielietot citus līdzekḷus iestādes mērḳa sasniegšanai. Kursa apjoms ir 3 KP jeb 2,7\% no kopējās programmas. Piecas stundas par šaujamieročiem paredzētas Dienesta organizācijas un Policijas tiesību studiju kursos.

Valsts Policijas koledžas (turpmāk - VPK) Policijas skolas programmā šaušanas mācība paredzēta 2,5 KP apjomā jeb 6,4\% no kopējās programmas.

Studiju kursa mērḳis VPK Policijas skolas programmai paredz iepazīstināt ar šaujamieroču pamatuzbūvi un tehniskajiem šaušanas paņēmieniem, kā arī šaujamieroču teorētisko un praktisko pielietošanu, ko jārealizē 96 stundās. VPK programma nosaka iegūtās iemaṇas un prasmes pielietot likumā noteiktajā kārtībā dažādās situācijās. Šis mērḳa formulējums liek domāt, ka moduḷu veidā vai situatīvās spēlēs / poligona 
treniṇos tiks trenētas iemaṇas un prasmes situācijās, kuras noteiktas likumā "Par policiju" kā gadījumi, kad var pielietot šaujamieroci. Tomēr, izvērtējot studiju kursa programmu, jāsecina, ka no 78 kursa stundām 28 kontaktstundas un 10 pastāvīgā darba stundas atvēlētas tēmai “Šaušanas taktika dažāāās situācijās". Tas ir lielākais stundu skaits no studiju kursā ietvertajām tēmām, tomēr vai pietiekami, lai sasniegtu kursa mērkị? Tāpat jāšaubās, kā studenti patstāvīgā darbā apgūs šaušanas taktiku dažādās situācijās.

VPK studiju programmas kompetences, prasmes un zināšanas ir atbilstīgas studiju kursa mērḳim, diemžēl to nevar novērtēt saskaṇā ar profesijas standartu, jo tāds nav izstrādāts. VPK programmā nav norādìtas kompetences un kā prasmes un zināšanas noteiktas policijas izmantojamo speciālo līdzekḷu, šaujamieroču, sakaru un tehnisko lïdzekḷ pielietošana.

Izanalizējot Valsts policijas koledžas īstenotās izglītības programmas, jāsecina nav iespējams izvērtēt programmu atbilstību Profesiju klasifikatoram. Tāpat jāšaubās, vai, apguvuši VPK Policijas skolas programmā iekḷautās studiju kursa tēmas, policijas darbinieki būs spējīgi îstenot likumā noteikto iestādes mērḳi - aizsargāt personu dzīvību, veselību, tiesības un brīvības, īpašumu, sabiedrības un valsts intereses no noziedzīgiem un prettiesiskiem apdraudējumiem un pielietot šaujamieroci galējas nepieciešamības gadījumā. Vai ar šo programmu tiek mācîts, kā, piemēram, pielietot šaujamieroci kiilnieku atbrīvošanas gadījumos vai atvairītu grupveida vai bruṇotu uzbrukumu? N̦emot vērā, ka šìs programmas absolventi ir skaitliski lielākā dal̦a policijas darbinieku, rodas pamatots jautājums, vai 2 . PKL atbilst nepieciešamajām zināšanām, prasmēm un ieman̦ām? Var jau kā argumentu minēt, ka Valsts policijā ir speciālas vienības, kuru uzdevums ir ìstenot speciālas operācijas un uzdevumus, tomēr likums ir noteicis visu policijas darbinieku tiesības un pienākumus izmantot šaujamieročus, neizdalot īpašas prasmes vai zināšanas kādai policijas darbinieku kategorijai. Arī Profesiju klasifikators neparedz policijas profesiju speciālo uzdevumu vienībā.

Valsts robežsardze îsteno trīs profesionālās izglītības programmas, bet autore analizēja tikai divas no tām, lai būtu iespēja vienlīdzịgi salīdzināt visu pētāmo iestāžu izglitiibas programmu saturu.

Tātad Valsts Robežsardzes koledžas (turpmāk - VRK) Robežsargu skola īsteno 3. PKL programmu $29 \mathrm{KP}$ apmērā un VRK jaunāko virsnieku programmu $80 \mathrm{KP}$ apjomā. Atškiriībā no VPK tās izglìtības programmas mērḳi ir atškịiīgi un atbilst profesijas standartos noteiktajām atškirīibām inspektora un jaunākā virsnieka profesijai.

Studiju kurss abās programmās ir nodēvēts identiski - "Ieroču un šaušanas mācība"; 1,5 KP Robežsargu skolā un 3 KP Valsts Robežsardzes koledžā. Salīdzinot ar Valsts policijas koledžas realizētajām izglìtības programmām, redzams, ka Valsts Policijas koledžas izglīiības programmu apjoms ir lielāks, kas būtu saistīts ar iestādes mērḳi. Valsts policijai tas ir plašāks un attiecas uz valsts funkciju visas sabiedrības veselïbas, dzìvības un mantas aizsardzību, savukārt Valsts robežsardze îsteno valsts funkciju - nodrošināt robežas neaizskaramību un novērst nelegālo imigrāciju. Ja ievēro šo likuma redukciju arī attiecībā uz galējas nepieciešamības gadỉjumā pielietot šaujamieroci, 
tad redzams, ka robežsargu tiesības pielietot šaujamieroci ir noteiktas mazākā apjomā nekā policijas darbiniekiem; un tas atbilst valsts funkciju īstenošanai. Tādējādi arī izglītības kursu programmai iestādē būtu jābūt pēc apjoma atšḳirīgai. Redzams, ka VRK Robežsargu skolā ieroču un šaušanas mācībai atvēlēts 1,5 KP no kopējā 29 KP apjoma, kas veido $5 \%$ izglitïbas programmas, bet VPK Policijas skolas programmas apjoms ir 6,4\% programmas. Tātad logiskā proporcionalitāte tiek saglabāta.

VRK programmā ieroču un šaušanas mācībai atvēlēti $3,75 \%$ no $80 \mathrm{KP}$, kas ir par 1,05\% vairāk nekā VPK, tāpēc var secināt, ka jaunāko virsnieku izglīî̄bas programmā nav ievērota likumā noteiktā diference attiecībā uz šaujamieroču izmantošanas kompetences apjomu. Tomēr praktiski šis fakts nerada problēmu, jo iestāde saskaņā ar tai delegeèto kompetenci var noteikt izglīīibas programmas saturu, ievērojot normatīvo aktu prasības.

Studiju kursa mērḳis VRK Robežsargu skolas programmā ir noteikts - iepazīstināt izglìtojamos ar šaujamieroču uzbūvi, darbības principiem un pielietošanas pan̄ēmieniem, kas, salīdzinot ar VRK programmas studiju kursa mērḳi - sniegt studējošajiem zināšanas ieroču šaušanas mācībā, pilnveidot iemaṇas dienesta šaujamieroču, munīcijas un speclīdzekḷu glabāšanā, apkopē un pielietošanā, lai to pielietotu padotā personāla apmācībā -, paredz, ka saskaṇā ar profesijas standartos noteikto jaunākā virsnieka programma atškiras.

Tomēr, vērtējot VRK Robežsargu skolas studiju programmā noteiktās kompetences, prasmes un iemañas, vērojamas zināmas atkāpes no profesijas standarta: abos dokumentos kompetences saskan, bet prasmes un zināšanas ir noteiktas tikai profesijas standartā, taču nav izdalītas studiju kursa programmā. VRK studiju kursa programmā un profesijas standartā nav noteiktas kompetences, bet atškịīibā no profesijas standarta, kurš neparedz nekādas prasmes jaunākajiem virsniekiem, studiju programma nosaka šaušanas vingrinājuma izpildes prasmi, kā arī prasmi plānot, organizēt un vadīt šaušanas nodarbības padotajam personālam (saskaṇā ar studiju kursa mērḳi noteikto). Konkrētu studiju kursa tēmu analīze norāda, ka šaušanas nodarbību plānošanas, organizēšanas un vadīšanas prasmes apmācībai ir veltìta viena tēma 12 stundu apjomā, kas ir otrs lielākais apjoms aiz praktiskās šaušanas apmācības nodarbībām. Tātad profesijas standartā iekḷautās zināšanas atspoguḷojas studiju kursa programmā.

Kopumā jāsecina, ka Valsts robežsardze ievēro profesijas standartā noteiktās prasības un ir tās iekḷāvusi izglīiības programmās, izṇemot dažas nianses, kas ir vienkārši novēršamas, veicot grozijumus izglītības programmās.

Ieslodzijjuma vietu pārvalde (turpmāk - IeVP) Mācību centrā īsteno 3. PKL jaunākā inspektora programmu. Ieslodzỉjuma vietu pārvaldei delegèēā valsts funkcija ir saturiski visšaurākā, kas attiecināma tikai uz kriminālsodu izpildes jomu noteiktās valsts vietās (cietumos), un arī šaujamieroču izmantošanas tiesiskais regulējums ir noteikts šaurāks pielietošanas kompetences apjoma ziṇā, bet vienlaikus paplašināts atsevišḳu gadījumu uzskaites zin̦ā (kazuistisks regulējums). Tāpēc arī izglîtības programma apjoma ziṇā ir visīsākā; tā noteikta $24 \mathrm{KP}$ apjomā, no kuriem tikai $1 \mathrm{KP}$ noteikts 
studiju kursa "Ieroči un šaušana" apgūšanai. Tas ir 4,2\% no kopējās izglīīibas programmas apjoma. Tādējādi procentuāli šaujamieroču apmācība IeVP ierindo starp VRS abām izglìtības programmām. VPK noteiktais KP skaits ir lielāks nekā IeVP saskaṇā ar normatīvo regulējumu. VPK programmā KP ir lielāks, jo lielāka ir VP kompetence šaujamieroču pielietošanā.

Studiju kursa mērḳis - sagatavot profesijas standartam atbilstīgus speciālistus un palīdzēt izglìtojamiem gūt priekšstatu par ieroču uzskaites un glabāšanas organizāciju, apgūt ieroču un munīcijas uzbūvi, drošības tehnikas noteikumiem un prasmi rīkoties ar ieročiem, precīzi šaut - precīzi atspoguḷots studiju programmā ietvertajās kompetencēs, prasmēs un zināšanās. Turklāt kompetences, prasmes un zināšanas pilnībā saskan ar profesijas standarta prasībām.

Kopumā jāsecina, ka IeVP Mācību centrā īstenotā izglīīibas programma vispilnīgāk saskan,ota ar profesijas standartu.

Lai varētu secināt, kā praksē tiek ìstenota amatpersonu kompetence šaujamieroču pielietošanā, būtu jāpēta tiesu prakse. Diemžēl publiski nav pieejami spriedumi par amatpersonu šaujamieroču izmantošanas gadỉjumiem, tāpēc nevar izteikt vispārinātus secinājumus par amatpersonu adekvātu darbību atbilstīgi noteiktajai kompetencei. Autorei izdevās atrast tikai vienu tiesu spriedumu [1], kur tiesa vērtēja šaujamieroča pielietošanu galējas nepieciešamības gadījumā, proti, ka ierocis tika izmantots, lai novērstu tā nokḷū̌šanu citas personas rokās, kura konkrētajā situācijā bija stiprā psihiskā uzbudinājumā. Tiesa norādīja, ka šaujamieroča nelikumīga pielietošana ir smags pārkāpums, kas vērsts uz citu sabiedrības locekḷu tiesību nopietnu apdraudējumu [1, 14. punkts]. Tomēr tā secināja, ka likumā "Par policiju" noteiktajos gadījumos policijas darbiniekam ir tiesības izvilkt šaujamieroci un sagatavot to šaušanai, ja viņš uzskata, ka konkrētajā situācijā nav izslēgta tā pielietošana vai izmantošana [1,11.2. punkts], bet tiesas ieskatā pieteicēja aprakstìtā situācija neietver reālas briesmas, kas varētu radīt galējās nepieciešamības stāvokli, kā arī minētā situācija neatbilst likuma "Par policiju" norādītajam, kad piel̦aujama šaujamieroča izmantošana $[1,11.3$. punkts]. Tādējādi šaujamieroča pielietošana tika atzìta par nelikumīgu un tika noraidìts pieteicēja apgalvojums, ka viṇš rīkojies galējas nepieciešamības gadījumā.

\section{Secinājumi}

1. Valsts ir delegeejusi savas funkcijas dažām iestādēm, tādējādi delegeējot arī tiesības izmantot šaujamieroci.

2. Cik lielā apjomā var tikt izmantotas tiesības uz šaujamieroča lietošanu, paredz likums, nosakot katras iestādes delegēejuma apjomu un tiesības izmantot šaujamieroci šì delegéjuma ietvaros, lai sasniegtu delegeejumā noteiktās funkcijas ìstenošanu.

3. Tādējādi Valsts policijai deleǵējums un tiesības izmantot šaujamieroci ir visplašākais - visa valsts teritorija, lai aizsargātu personu dzīvību, veselību, tiesības, brīvības, īpašumu un intereses. Valsts robežsardzei deleǵējums ir šaurāks un 
šaurākas ir arī tiesības izmantot šaujamieroci, kas izriet no iestādei delegètās funkcijas - valsts robežas neaizskaramības nodrošināšana un nelegālās imigrācijas novēršana. Kaut gan teritoriāli šo funkciju ir jāīsteno visas valsts teritorijā, piẹ̦aujamie gadījumi, kad var pielietot šaujamieroci, ir apjoma ziṇā šaurāki. Ieslodzijjuma vietu pārvalde pilda valsts funkciju tikai kriminālsodu izpildes jomā, un teritoriāli tas attiecināms uz dažām valsts vietām (cietumiem).

4. Lai iestāde varētu îstenot tai noteikto funkciju un likumā noteiktajā kārtībā pielietotu šaujamieroci, būtiski ir veikt amatpersonu izglïtošanu, kuras rezultātā tiktu iegūta attiecīga profesionālā kompetence. Ar kompetentu amatpersonu darbību iestāde sasniedz likumā noteikto mērḳi.

5. Valsts funkcijas delegēejums, kas atspoguḷots likumā noteiktā iestādes mērḳī, atšķiras, tāpēc būtu jāatšḳiras arī profesijas standartā noteiktajām kompetencēm un izglītibas programmas saturam.

6. Profesiju klasifikatorā nav ietverts neviens profesijas standarts Valsts policijas profesijām, tāpēc neviena izglìīibas iestāde nevar ìstenot izglìtības programmas, kuru rezultātā tiek sagatavoti speciālisti kādā no policijas profesijām. Profesijas standartus visām trim Profesiju klasifikatorā iekḷautajām profesijām izstrādājusi Valsts robežsardze, bet Ieslodzijuma vietu pārvalde no Profesiju klasifikatorā iekḷautajām 11 profesijām izstrādājusi vienu profesijas standartu - zemākajai profesijai - jaunākais inspektors.

7. Priekšlikums: valstij jānodrošina kontroles mehānisms, izmantojot studiju virzienu akreditācijas procesu, un tai nevajadzētu akreditēt tos virzienus, kuru izglïtības programmas izstrādātas bez attiecīga procesijas standarta vai spēkā esoša profesijas standarta. Lai arī pašlaik spēkā esošajos Augstskolu, koledžu un studiju virzienu akreditācijas noteikumos [2] ir paredzēts, ka akreditācija notiek, ja studiju programma, virziens izstrādāti, balstoties uz profesijas standartiem, šajā pētijumā tika noskaidrots, ka reāli tas tā nenotiek. Tāpēc nepieciešams pastiprināt akreditācijas komisijas atbildību par pieņemtajiem lēmumiem. Autore piedāvā Augstskolu, koledžu un studiju virzienu akreditācijas noteikumu 8. punktu, kurā noteikta akreditācijas komisijas atbildība, papildināt ar apakšpunktu šāāa redakcijā "8.9. ir atbildìga par akreditācijas lēmuma tiesiskumu".

8. Profesijas standarts nosaka profesionālās kvalifikācijas līmenim atbilstīgu personas gatavību veikt attiecīgos profesijas pienākumus. Tāpēc kompetencēm katrā līmenī būtu jāatšḳiras. Piemēram, inspektoram svarīgi šaut praktiski un saprast, kādos gadījumos var un nevar pielietot šaujamieroci; jaunākajam virsniekam svarīgi ne tikai pašam šaut praktiski, bet arī prast apmācìt šaušanas teorētiskos un praktiskos pamatus padotajam personālam; bet vecākajam virsniekam jābūt ne tikai praktiskām un teorētiskām zināšanām, bet arī kompetencei plānot un organizēt šaušanas apmācības. Tikai šādā logiiskā profesionālās kvalifikācijas līmen,u ceḷā var tikt sagatavoti profesijas klasifikācijai atbilstīgi profesionāḷi. 
9. Praktiski redzams, ka VPK 2. PKL un 4. PKL programmā ir iestrādāti identiski izglīīibas programmas mērḳi, kas neḷauj sagatavot profesionālās kvalifikācijas līmenim atbilstīgus profesionālus.

10. VRK Robežsargu skolas izglīiības programmā kompetences, prasmes un zināšanas nedaudz atšḳiras no profesijas standartā noteiktā.

11. Priekšlikums: būtu nepieciešams precizēt izglītỉbas programmu "Ieroču un šaušanas mācības" kursā.

12. Kopumā iestādes ìsteno likumā delegeèto valsts funkciju, un jautājumā par šaujamieroča izmantošanu izglīīibas sistēma ir izstrādāta, ievērojot normatīvo aktu prasības. Turpretī Valsts policija kā darba devējs līdz 2015. gada 1. decembrim nav izveidojusi profesiju standartus, lai izglìīibas iestāde varētu izstrādāt izglītības programmu, kas balstìtos uz normatīvajos aktos noteiktām kompetencēm.

13. Priekšlikums: visām iestādēm izglītỉbas programmās iekḷaut ne tikai tēmu iedalījumu šaujamieroča pielietošanas apgūšanai, bet arī ieviest moduḷu apmācību, kurā tiktu simulētas konkrētas situācijas, lai mācības pietuvinātu reālās dzīves apstākḷiem, kādos amatpersonai var nākties pien,emt lēmumu un pielietot šaujamieroci.

14. Publiski nav pieejami tiesas spriedumi, kas l̦autu izteikt vispārīgus secinājumus par amatpersonu kompetenci vai nekompetenci, izmantojot šaujamieroci.

\section{The Legal Use of Firearms and Professional Education of State Officials}

\section{Abstract}

Every democratic society has respect for basic human rights and liberties that are acknowledged by the State as having value and are preserved. To preserve such values the State with the help of Law has determined to restrict human rights and liberties. One of the basic values is the right to live which is not meant to be restricted. On the other hand, the State has granted the right to use a firearm by the State employed officials in the exclusive cases pointed out by the Legislator in special legal regulations. Such a situation presumes a conclusion that in case of firearms' utilization an individual's rights to life and health, which are recognized by the State itself, are put in jeopardy. In order to ensure a correct use of firearms, the State must create legal regulations that would control the system of professional education, enabling an officer to gain their professional competence there.

The Author reviews three institutions of which the employees have the right to use a firearm - The State Police, The State Border Guard and The Prison Administration. 
Kitija Bite. Šaujamieroču pielietošanas tiesības un amatpersonu profesionālā izglītība

The article gives an insight into the law of firearm utilization and an analysis of such legal regulations that regard the development of professional competencies in the framework of formal education.

Keywords: human rights, use of firearms, extreme necessity, profession's standard, professional education, education programme, study course.

\section{Literatūra}

1. Administratīiās apgabaltiesas 27.03.2009. spriedums lietā Nr.AA43-1663-09/19.

2. Augstskolu, koledžu un studiju virzienu akreditācijas noteikumi: Ministru kabineta 14.07.2015. noteikumi Nr. 407. Latvijas Vēstnesis, 146, 29.07.2015.

3. Dišlers, K. Ievads administratīvo tiesību zinātnē. Rīga: Latvijas Universitāte, 1938. 246 lpp.

4. Dokumenti par Latvijas valsts starptautisko atzī̌anu, neatkarības atjaunošanu un diplomātiskajiem sakariem 1918.-1998./Sast. dr. hum. A. Sarkanis. Rìga: Nordik, 1999. 542 lpp.

5. Eiropas cilvēktiesību un pamatvērtību aizsardzības konvencija: starptautisks dokuments. Iegūts no: http://www.humanrights.lv/doc/regional/eckkons.htm [sk. 07.10.2015.].

6. Eiropas Padomes Parlamentārās asamblejas 1979. gada 8. maija 690. rezolūcija Par deklarāciju par policiju, A dal̦a Ėtika, 12. punkts.

7. Ierindas sastāva policista (2PKL) spēkā neesošs profesijas standarts. Iegūts no: http://www. niid.lv/niid_search/program/916?qy=policijas\%20darbs\&level_1=\&qualification=Vid\%C 4\%93j\%C4\% 81\%2 0komand\%C4\%93jo\% C5\%A 1\%C4\%81\%20\%28jaun\%C4\%81 ko\%20virsnieku\%29\%20sast\%C4\%81va\%20policists\%404 [sk. 20.08.2015.].

8. Ieslodzījuma vietu pārvaldes likums: Latvijas Republikas likums. Latvijas Vēstnesis, 168 (2743), 19.11.2002.

9. Izglìtības un zinātnes ministrija. Profesijas standarti. Iegūts no: http://www.izm.gov.lv/lv/izglitiba/augstaka-izglitiba/profesiju-standarti [sk. 17.08.2015.].

10. Judins, A. Kriminālatbildības izslēdzamības apstākḷi. Rīga: Tiesu nama agentūra, 2000. 265 lpp.

11. Latvijas Republikas Satversme: Latvijas Republikas likums. Latvijas Vēstnesis, 43, 01.07.1993.

12. Latvijas Republikas Satversmes komentāri / R. Baloža zin. redakcijā. Latvijas Vēstnesis, 2011. 864 lpp.

13. Likums "Par policiju”: Latvijas Republikas likums. Ziṇotājs, 37, 24.09.1992.

14. Par profesiju klasifikatoru, profesijai atbilstošo pamatuzdevumu un kvalifikācijas pamatprasību, profesiju klasifikatora lietošanas un aktualizēšanas kārtību: Ministru kabineta 18.05.2010. noteikumi Nr. 461. Latvijas Vēstnesis, 84, 28.05.2010.

15. Profesionālās izglītības likums: Latvijas Republikas likums. Latvijas Vēstnesis, 213/215, 30.06.1999.

16. Profesiju standartu izstrādes kārtība: Ministru kabineta 27.02.2007. noteikumi Nr. 149. Latvijas Vēstnesis, 37, 02.03.2007.

17. Valsts robežsardzes likums: Latvijas Republikas likums. Latvijas Vēstnesis, 329/330 (1044/1045), 16.12.1997.

18. Vidējā komandējošā (jaunāko virsnieku) sastāva policista (4PKL) spēkā neesošs profesijas standarts. Pieejams: http://www.niid.lv/niid_search/program/21063?qy=policijas\%20darbs\&level_ 1=\&qualification=Ierindas\%20sast\%C4\%81va\%20policists $\% 402$ [sk. 20.08.2015.]. 
Kitija Bite. Šaujamieroču pielietošanas tiesības un amatpersonu profesionālā izglītība

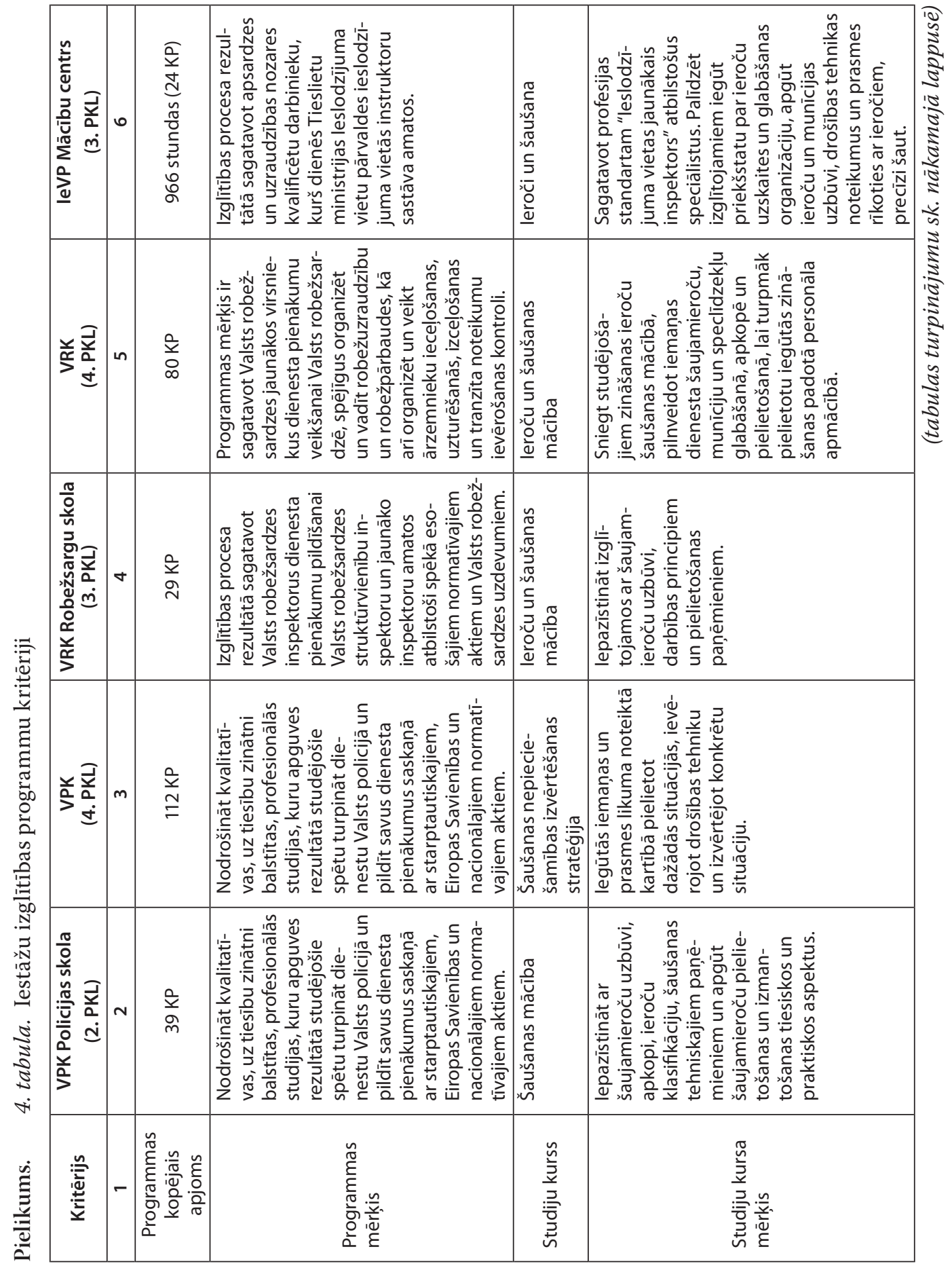


Kitija Bite. Šaujamieroču pielietošanas tiesības un amatpersonu profesionālā izglītība

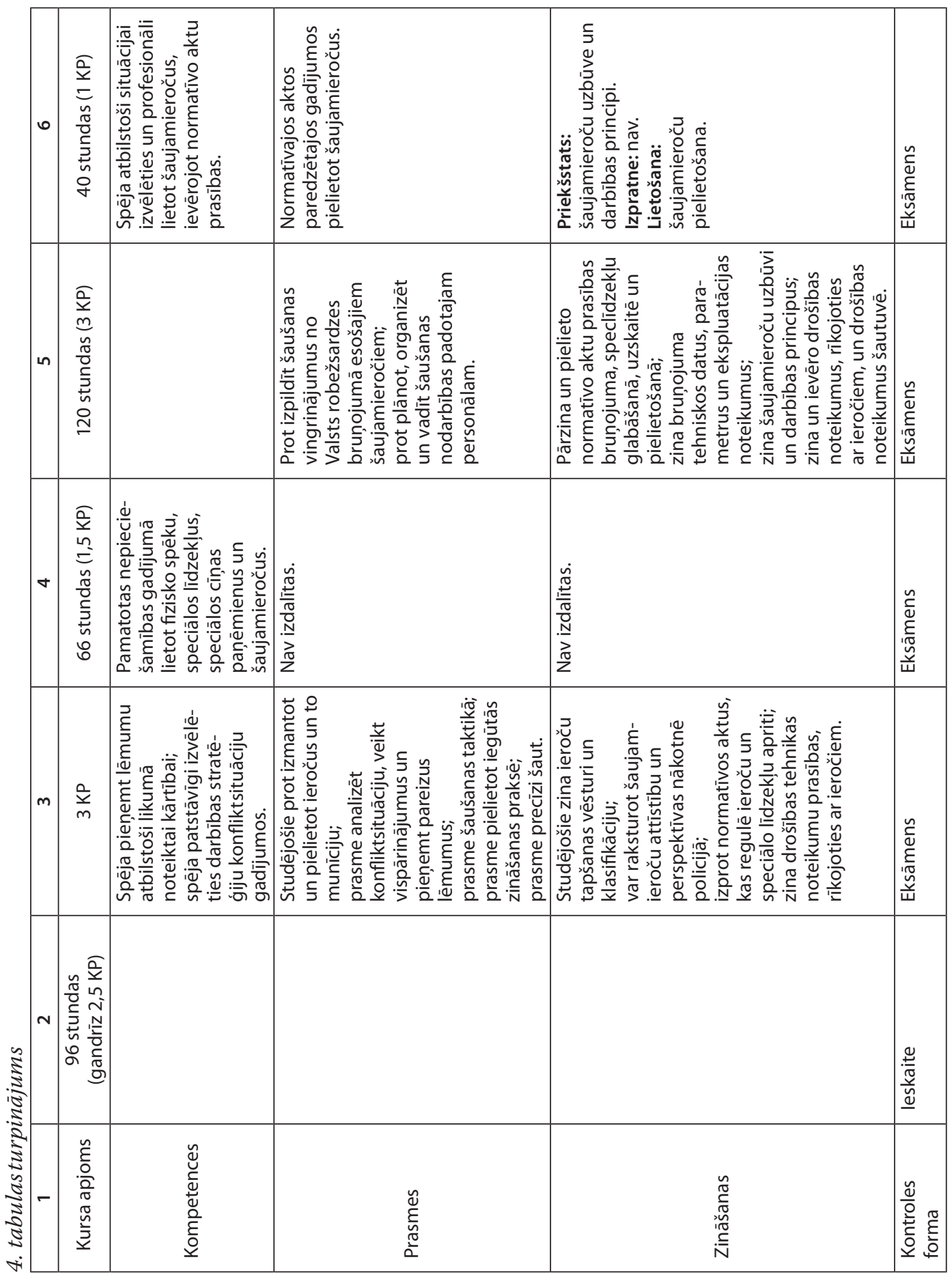

